\title{
名前の話一昔の名前で出ています一
}

\section{尾山 由紀子（東京大学大学院工学系研究科）}

男女共同参画委員の皆様の活動や先輩方の活躍により制度 等の整備や意識改革が着実に進み, 女性研究者として大変恵 まれた環境に身をおかせて頂いていると日々感じています。 結婚，子育てという個人的な環境の激変に対して，少ないな がらもロールモデルとなってくれる先輩方の存在は心強い限 りです．学会の大会においては託児所の設置されるケースが 増えています。東京大学では, 女性研究者サポート要員の配 置プログラムの試行が行なわれ，子育て，介護などと研究の 両立に必要な人的サポートについての検討が進められていま す.

電気化学会の大会に行くと比較的女性が多いように思いま す。ただ，分野別に見ると差がずいぶんあるのかもしれませ ん. 先日参加した第 35 回固体イオニクス討論会（大阪）に おいて 102 件の発表のうち女性が発表した件数は全体の約 8\%でした。会場ではおそらく学生であろう女性が増えてい るように感じましたが，数字を見るとまだ増えてもいいのか もしれません．女性の参加が少ないのは当たり前と思ってい る私自身の意識改革も必要かもしれません，同じ分野での国 際会議ではもっと女性がいたように思います。私がこの分野 の国際会議に初めて参加したのは，2005年，第 15 回固体イ オニクス国際会議（SSI-15，バーデンバーデン（ドイッ）） でした。その時，会場で特にヨーロッパの女性研究者が多い ことが印象的でした。2008年に京都で開催された第14回固 体プロトン伝導体国際会議（SSPC-14）では，実行委員とし ても参加したのですが，思い返すとやはり女性の参加者が多 かったように思い，改めて参加者リストを数えてみたところ， Accompanying personを除く参加者の女性の比率は約 18 . $2 \%$ ．参加者全体で見ると国内からの参加者が多かったにも かかわらず，女性だけで見ると $4 / 5$ は外国からの参加者で した。海外との女性研究者の比率を反映しているのでしょう. 最近，その会議に参加していた女性の一人が私の所属してい る研究室にポスドクとしてスウェーデンから来ました. 旦那 様を伴っての来日. 2 年間休職できる制度を利用して同伴さ れてきたとのこと．日本ではなかなか考えにくいライフスタ イルに驚きました。

さて, 気になっている点があります。名前 (苗字) のこと です。夫婦別姓という法整備を必要とする大問題にまで話を 広げるつもりではありません. 研究の上で皆さんどうされて いるのでしょうか？女性のほうが多いと思いますが，男性で も変更されている方は少なからずいらっしゃると思います.

改姓後，職場への届出を初め，運転免許証，銀行口座等々， 様々な事務的な変更手続きを行ないました，全て完了するの にずいぶん時間がかかった気がします。幸い，一番初めに変 更手続きを行なった運転免許証が表は旧姓, 裏に変更事項と して，現在の姓，本籍などをすべて記されているものになっ ていたので，この一枚のお陰で様々な変更手続きをスムーズ に進めることができました。 パスポートは改姓に伴い，新し く作成するか，改姓手続きの 2 つ方法がありましたが，当
時，有効期限がずいぶん残っていたので，手数料が安く，そ の日のうちに手続きの済む後者を選びました．結果として， パスポートのラミネートされている写真のページの名前等は 変更されず “前のページを見よ“という記述のもと, そのぺ ージには変更事項の名前, 本籍地の記載された表が印刷され, 追記されていました。この場合，パスポートの署名は変更さ れません，入国審査書類の署名は前のままのものを使うこと になります．決められたルールなので仕方ありません。

現在，仕事の上では，旧姓を使っています。大学には“旧 姓使用許可”を申請し，使用を認めてもらっていることにな っています。特に強いこだわりがあったというよりも，ただ 変更が “面倒”だと思ったからが理由です。事実上，この使 用許可をもとに, 仕事上は学外においても旧姓を名乗ってい ます。

女性研究者の先輩には職場のルールで旧姓使用のルールが 整備されておらず，認められていなかったためにやむを得ず 変更されたという例，括弧書きで併記されている例もありま した。もちろん，制度が整っている状況においてもスパッと 改姓される方も多々いらっしゃいます。しかし，私の周囲を 見たところ，旧姓のままの方のほうが多いようです。論文に おける名前表記では，ミドルネームで併記されている例は 多々見られます。日本人の場合，日本語では改姓後の苗字の み書いてあり，ローマ字表記ではミドルネームとして旧姓を 挿入していらっしゃる場合もあるかと思います。

論文での名前，活動上の名前，どのように考えたらよいの でしょうか? 国会議員でもかつての芸名のまま活動されてい るいわゆるタレント議員の方もいらっしゃいます．作家でい えばペンネームにあたるのでしょうか？

法的な規制のある先ほどのパスポートの例や, 納税などで は明確に現在の姓の使用が求められますが, 論文, 学会発表 といった際に学会ごとにルールというのはあるのでしょう か?（見つけていないだけかもしれません.）苗字が異なる 業績は認められないという問題は本当にあるのでしょうか?

例えば，著作権の譲渡などといった契約は仕事上の名前で 大丈夫なのでしょうか？今のところ様々な問題に遭っていな いためにやり過ごしているだけなのではないかと思うことが あります。先輩方の経験談や専門家の見解をお聞きしたいと 思うこともあります。研究に多大な影響を与えることではな い，まったく些細なことなので，気にしなくてもいいことな のかもしれませんがなんとなく気になり続けているのです.

自分の名前を書く機会を考えると圧倒的に仕事上の名前の ほうが多いと思います。先日，とある申請書に本姓を記述す ることがあり，提出したところ，空口で“名前のローマ字の スペルが間違っていますよ!”と指摘されてしまいました。 タイプミスしていました．自分の名前のはずですがまったく 慣れていません.

皆さんの周りではどのようにされているのでしょうか？ 